\title{
Deodorant Activity of Black Cumin Seed Essential Oil against Garlic Organosulfur Compound
}

\author{
Yuri Yoshioka $^{1}$, Shinichi Matsumura ${ }^{1}$ (D) and Masanori Morimoto ${ }^{2, *(D)}$ \\ 1 Natural Products, Inabata Koryo Co., Ltd., Yodogawa, Osaka 532-0027, Japan; \\ y-yoshioka@inabatakoryo.co.jp (Y.Y.); shin-matsumura@inabatakoryo.co.jp (S.M.) \\ 2 Department of Applied Biological Chemistry, School of Agriculture, Kindai University, Nara 631-8505, Japan \\ * Correspondence: masanori@nara.kindai.ac.jp; Tel.: +81-742-43-7162
}

Citation: Yoshioka, Y.; Matsumura,

S.; Morimoto, M. Deodorant Activity of Black Cumin Seed Essential Oil against Garlic Organosulfur Compound. Biomolecules 2021, 11, 1874. https://doi.org/10.3390/ biom11121874

Academic Editor: Naoko Goto-Inoue

Received: 16 November 2021

Accepted: 9 December 2021

Published: 14 December 2021

Publisher's Note: MDPI stays neutral with regard to jurisdictional claims in published maps and institutional affiliations.

Copyright: (c) 2021 by the authors. Licensee MDPI, Basel, Switzerland. This article is an open access article distributed under the terms and conditions of the Creative Commons Attribution (CC BY) license (https:// creativecommons.org/licenses/by/ $4.0 /)$.

\begin{abstract}
The deodorant activity of black cumin (Nigella sativa L.) seed, a spice used to flavor curry and vegetable foods in Southwest Asia, against garlic (Allium sativum L.) organosulfur compounds related to human malodor was evaluated. Black cumin seed essential oil showed remarkable deodorant activity against garlic essential oil. The mode of action of this deodorant activity was presumed to be that black cumin seed essential oil covalently reacted with the organosulfur compounds in garlic. Therefore, thymoquinone, which is a major constituent in black cumin seed essential oil, and allyl mercaptan, which is one of the organosulfur compounds produced by cutting garlic, were reacted in vitro, and the products were purified and elucidated using spectroscopic data. As a result, these substances were identified as different allyl mercaptan adducts to dihydrothymoquinone. This chemical reaction was presumed to play a key role in the deodorant activity of black cumin seed essential oil.
\end{abstract}

Keywords: black cumin seed essential oil; deodorant activity; garlic organosulfur compounds; Nigella sativa L.

\section{Introduction}

Black cumin (Nigella sativa L.) seed is a species of the Ranunculaceae family, and thymoquinone is a major component of black cumin seed essential oil. Black cumin seed essential oil (BCO) exhibits various beneficial effects, including restoring the antioxidant defense system, increasing the activity of antioxidant-related enzymes, decreasing inflammatory biomarkers, suppressing pro-inflammatory mediator production, preventing endothelial dysfunction, and improving hepatic, kidney, heart, and immune system functions [1].

Garlic (Allium sativum L.) is a species of the Amaryllidaceae family and is used as a food and spice worldwide. This plant exhibits various functions, such as antibacterial, antiviral, antioxidant, and anti-inflammatory effects [2]. However, garlic food products contain various organosulfur compounds that lead to bad breath, and the odor lasts for a long time after ingestion. For this reason, many people often hesitate to eat garlic products [3].

Halitosis and a peculiar garlic odor are common after the ingestion of garlic products. In the oral cavity, garlic fragments result in methyl mercaptan (MM) and hydrogen sulfide, leading to bad breath from these food products. MM and hydrogen sulfide are common causes of malodorous breath exhaled from the normal human body. In addition, other organosulfur compounds, including allyl mercaptan (AM) and allyl methyl sulfide (AMS), result from digestion in the stomach, and these chemicals are released as exhaled breath and excreted through sweat glands and sebaceous glands by the bloodstream, leading to body odor [4].

Since MM is a primary factor for halitosis, it has been studied extensively [1]. There have been several reports concerning halitosis prevention using plant materials against MM. Thyme (Thymus vulgaris L.) and rosemary (Rosmarinus officinalis L.) have both shown 
remarkable deodorant activity against MM [5]. Phenolic compounds, such as chlorogenic acid, caffeic acid, and tea catechin, can also be used as deodorizing agents against MM [6,7]. In addition, $\mathrm{BCO}$, which was used in this study, has been reported to show strong deodorant activity against $\mathrm{MM}$. The active ingredient of $\mathrm{BCO}$ is thymoquinone, whose deodorant activity exceeds that of tea catechin [8]. The deodorizing mechanism of $\mathrm{BCO}$ is presumed to be related to the binding of the mercapto group of MM [9].

After garlic ingestion, human exhalation acquires a peculiar odor. Furthermore, garlic is absorbed into the body by digestion, causing a bad smell to be released from the whole body, including exhaled breath. Previous studies on exhaled breath components related to garlic ingestion have revealed several volatile organosulfur compounds associated with the characteristic odor of garlic in exhaled breath, such as diallyl disulfide (DADS) and AMS $[10,11]$. DADS and AMS are detected in high concentrations in human exhaled breath immediately after garlic ingestion [11-13]. The digestion of AMS takes several hours, and AMS has been reported to be responsible for the persistent odor of garlic in exhaled breath. ${ }^{14)}$ In addition, AMS and DADS have been reported as body odors on the skin surface after the ingestion of garlic [14]. However, there are few reports of deodorant activity against garlic odor, and this mechanism has not been clarified.

Common halitosis is generated from food fragments in the oral cavity, and there have been many reports on deodorant activity in mimicked oral environments, in which the $\mathrm{pH}$ is neutral and food is present for a short time. However, when it comes to halitosis after garlic ingestion, it is necessary to assume the environmental conditions of the stomach, that is, where the $\mathrm{pH}$ is acidic and there is residual time regarding the presence of food. There have been several reports on gastric emptying time. Degen et al. compared men and women and reported that the median gastric emptying time (T 1/2) was approximately $150 \mathrm{~min}$ for men and approximately $200 \mathrm{~min}$ for women [15]. Hellmig et al. reported that the median gastric emptying time (T 1/2) was $80.5 \pm 22.2 \mathrm{~min}$ for liquids and $127 \mathrm{~min}$ for solids, although not normally distributed [16].

Accordingly, we evaluated the deodorant activity of both conditions, with an oral cavity mimic at $\mathrm{pH} 7.0$ and a gastric environment mimic at $\mathrm{pH}$ 1.2. The duration of the deodorant test was decided in consideration of the residual time of food in the stomach, as per a previous paper. We evaluated whether $\mathrm{BCO}$, which has a deodorizing effect against MM, is also effective for the volatile organosulfur compounds of garlic that cause bad breath after garlic ingestion. Furthermore, the reaction products between AM and thymoquinone, which is a major constituent in BCO, were isolated and the chemical structures were elucidated to help us better understand the deodorizing mechanism.

\section{Materials and Methods}

\subsection{General Experimental Procedures}

One- and two-dimensional nuclear magnetic resonance (NMR) spectra were obtained using an Avance 400 instrument (Bruker Co., Ltd., Bremen, Germany), with a solvent signal of $\mathrm{CDCl}_{3}$ as the internal reference. Gas chromatography-mass spectrometry (GC-MS) analyses were performed using an Agilent 7890A-5975C MSD instrument (Agilent Technologies, Santa Clara, CA, USA). Desorption electron ionization (DEI-MS) was measured using JEOL JMS-K9 (JEOL Co. Ltd., Tokyo, Japan). Headspace-gas chromatography (HS-GC) analyses were performed using an Agilent 6890 GC instrument (Agilent Technologies), which was equipped with a pulsed flame photometric detector (PFPD, model 5380, Agilent Technologies). Liquid chromatography-mass spectrometry (LC-MS) analyses were performed using an ultra-performance liquid chromatography-mass spectrometry system (LCMS-8050, Shimadzu, Kyoto, Japan), which was equipped with Lab Solutions Version 5.75. Flash column chromatography was performed on an Isolera One instrument (Biotage, Uppsala, Sweden). 


\subsection{Botanical Essential Oils}

Black cumin (N. sativa) seed essential oil (BCO, thymoquinone content of $41.5 \%(v / v))$ was purchased from Arjuna Natural (Cochin, India). Garlic (A. sativum) essential oil (GEO) was purchased from Plant Lipids (Cochin, India). Both BCO and GEO were manufactured industrially by steam distillation.

\subsection{Chemicals}

Allyl mercaptan (AM, purity $84.6 \%$ ), allyl methyl sulfide (AMS, purity $99.1 \%$ ), diallyl sulfide (DAS, purity $99.7 \%$ ), allyl methyl disulfide (AMDS, purity $95.6 \%$ ), dimethyl trisulfide (DMTS, purity $99.6 \%$ ), and diallyl disulfide (DADS, purity $84.1 \%$ ) were purchased from Tokyo Chemical Industry Co., Ltd. (Tokyo, Japan). Allyl methyl trisulfide (AMTS) and diallyl trisulfide (DATS) were isolated from GEO.

\subsection{Isolation of AMTS and DATS from GEO}

GEO (100 g, including AMTS 10.0\% and DATS 45.2\%) was distilled under reduced pressure (temperature, $70^{\circ} \mathrm{C}$; vacuum, $0.5 \mathrm{kPa}$ for $1 \mathrm{~h}$ ), and garlic distillation oil (GDO, $24.1 \mathrm{~g}$, including AMTS 15.7\% and DATS 9.4\%) and its residue of GEO after distillation (RGO, $68.4 \mathrm{~g}$, including AMTS 9.4\% and DATS 67.5\%) were obtained. GDO (8 g) was then loaded into a preparative high-performance liquid chromatography (HPLC) system (Shimadzu), using the following parameters: column, L-column ODS (separation column $20 \mathrm{~mm}$ I.D. $\times 250 \mathrm{~mm}$, particle size $5 \mu \mathrm{m}$, guard column $10 \mathrm{~mm}$ I.D. $\times 20 \mathrm{~mm}$, particle size $5 \mu \mathrm{m}$, Chemicals Evaluation and Research Institute, Tokyo, Japan); column temperature, ambient; mobile phase, water:acetonitrile $=25: 75$; flow rate, $18.9 \mathrm{~mL} / \mathrm{min}$; injection volume, $400 \mu \mathrm{L}$; and a photodiode array detector. UV absorption was monitored at 190 and $214 \mathrm{~nm}$. Under these conditions, the two fractions with peaks at $8 \mathrm{~min}$ and $10 \mathrm{~min}$ were collected and concentrated to obtain GDO Fraction 1 (yield $3.24 \mathrm{~g}$ ) and GDO Fraction 2 (yield $0.52 \mathrm{~g}$ ), respectively. GDO Fraction 1 was again purified in the same preparative HPLC system with a different method using a mobile phase of water:acetonitrile $=30: 70$ and an injection volume of $50 \mu \mathrm{L}$. The fraction with a peak at $10.5 \mathrm{~min}$ was collected and concentrated to obtain GDO Fraction 3 (yield $0.33 \mathrm{~g}$ ) [17-19]. GDO Fraction 2 and GDO Fraction 3 were identified as DATS (purity 95.8\%) and AMTS (purity 98.4\%) by GC-MS analysis, respectively. Furthermore, these isolated compounds were identified using NMR spectra.

Allyl methyl trisulfide (AMTS): ${ }^{1} \mathrm{H}$ NMR $(400 \mathrm{MHz}) \mathrm{CDCl}_{3} \delta(\mathrm{ppm}): 5.89(1 \mathrm{H}, \mathrm{ddt}$, $J=16.9,9.97,7.34 \mathrm{~Hz}), 5.23(1 \mathrm{H}, \mathrm{dd}, J=16.9,1.38 \mathrm{~Hz}), 5.20(1 \mathrm{H}, \mathrm{dd}, J=9.97,1.38 \mathrm{~Hz}), 3.51$ $(2 \mathrm{H}, \mathrm{d}, J=7.34 \mathrm{~Hz}), 2.56(3 \mathrm{H}, \mathrm{s}) .{ }^{13} \mathrm{C} \mathrm{NMR}(100 \mathrm{MHz}) \mathrm{CDCl}_{3} \delta(\mathrm{ppm}): 132.7,119.1,41.5$, 22.8. EIMS (70 eV) $m / z$ (relative intensity, \%); $152\left(\mathrm{M}^{+}, 10.7\right), 111$ (17.0), 87 (100), 79 (15.1), 73 (82.1), 64 (12.3), 45 (43.5).

Diallyl trisulfide (DATS): ${ }^{1} \mathrm{H}$ NMR $(400 \mathrm{MHz}) \mathrm{CDCl}_{3} \delta(\mathrm{ppm}): 5.88(2 \mathrm{H}, \mathrm{ddt}, J=16.8$, 9.79, $7.28 \mathrm{~Hz}), 5.23(2 \mathrm{H}, \mathrm{dd}, J=16.8,1.38 \mathrm{~Hz}), 5.20(2 \mathrm{H}, \mathrm{dd}, J=9.79,1.38 \mathrm{~Hz}), 3.51(4 \mathrm{H}, \mathrm{d}$, $J=7.28 \mathrm{~Hz}) .{ }^{13} \mathrm{C}$ NMR $(100 \mathrm{MHz}) \mathrm{CDCl}_{3} \delta$ (ppm): 132.7, 119.1, 41.6. EIMS $(70 \mathrm{eV}) \mathrm{m} / z$ (relative intensity, \%); $178\left(\mathrm{M}^{+}, 8.0\right), 113(100), 73$ (97.9), 41 (60.1).

\subsection{GC-MS Analysis}

The following GC-MS analytical conditions were used: column, InertCap Pure-WAX ( $60 \mathrm{~m} \times 0.25 \mathrm{~mm}$ I.D., $0.25 \mathrm{~mm}$ film thickness, GL Sciences, Inc., Tokyo, Japan); injection temperature, $250^{\circ} \mathrm{C}$; injection volume, $1 \mu \mathrm{L}$; split ratio, $80: 1$; carrier gas flow, $1.2 \mathrm{~mL} / \mathrm{min}$ (helium, constant flow); temperature program, $50{ }^{\circ} \mathrm{C}(2 \mathrm{~min}$ hold $), 50-240{ }^{\circ} \mathrm{C}$ at $2.5^{\circ} \mathrm{C} / \mathrm{min}$ and $240{ }^{\circ} \mathrm{C}$ (50 min hold); ion source temperature, $230^{\circ} \mathrm{C}$; and quadrupole temperature, $150^{\circ} \mathrm{C}$. Ionization was performed using the electron impact ionization method at $70 \mathrm{eV}$ (scan range 25-350 $\mathrm{m} / \mathrm{z}$ ). The constituents of the essential oil were identified using the NIST MS library (NIST 08) (National Institute of Standards and Technology, Standard Reference Data, Gaithersburg, MD, USA) and the Wiley MS Library (Version 7) (Cerno Bioscience, Las Vegas, NV, USA) along with retention indexes. The content of each component was shown as the area percentage relative to the total area of detected peaks in the GC-MS analysis. 


\subsection{HS-GC Analysis}

The following HS-GC analytical conditions were used: column, InertCap Pure-WAX $(60 \mathrm{~m} \times 0.25 \mathrm{~mm}$ I.D., $0.25 \mathrm{~mm}$ film thickness, GL Sciences, Inc.); injection temperature, $250{ }^{\circ} \mathrm{C}$; injection volume, $1 \mathrm{~mL}$ (headspace gas); split ratio, 10:1; carrier gas flow, $1.2 \mathrm{~mL} / \mathrm{min}$ (helium, constant flow); and temperature program, $50{ }^{\circ} \mathrm{C}$ ( $2 \mathrm{~min}$ hold), $50-200{ }^{\circ} \mathrm{C}$ at $7.5^{\circ} \mathrm{C} / \mathrm{min}$ and $200-240{ }^{\circ} \mathrm{C}$ at $20{ }^{\circ} \mathrm{C} / \mathrm{min}$. The constituents of the essential oil were identified based on the retention times of commercial reagents [20].

\subsection{Evaluation of Deodorant Activity}

The deodorant activity of BCO against GEO and the organosulfur compounds in garlic was evaluated using the headspace method. The disintegration test solution $(\mathrm{pH}$ 1.2) used was diluted, 1st fluid for disintegration test, $\mathrm{pH} 1.2 / 1$ st fluid for dissolution test, pH $1.2(\times 10)$ (Wako 066-06441, Fujifilm Wako Pure Chemical, Tokyo, Japan), with ion-exchanged water ( $\mathrm{pH} 1.2$ test solution). The phosphate buffer ( $\mathrm{pH} 7.0)$ used was an instant phosphate buffer (RM-102-3 L, LSI Medience Corporation, Tokyo, Japan). GEO and the eight major organosulfur compounds in garlic were prepared with ethanol to defined concentrations (GEO, $300 \mathrm{ng} / \mu \mathrm{L}$; AM, AMS, DAS, AMDS, DMTS, and DADS, $10 \mathrm{ng} / \mu \mathrm{L}$; AMTS, $500 \mathrm{ng} / \mu \mathrm{L}$; and DATS, $1000 \mathrm{ng} / \mu \mathrm{L}$ ). These concentrations of organosulfur compounds were adjusted under PFPD saturation. The BCO ethanolic solution $(1 \mathrm{~mL})$ and $\mathrm{pH}$ 1.2 test solution or $\mathrm{pH} 7.0$ buffer $(5 \mathrm{~mL})$ were mixed in a $30 \mathrm{~mL}$ glass vial and sealed with a silicone cap. After adding $50 \mu \mathrm{L}$ of GEO or organosulfur compound ethanolic solution, the glass vial was shaken strongly for $1 \mathrm{~min}$. The mixture was then left standing at $37^{\circ} \mathrm{C}$ for 60, 120, and 180 min with GEO; 10 min with AM; 120 min with AMS, DAS, and AMDS; and 180 min with DMTS, DADS, AMTS, and DATS. The organosulfur compounds released to the headspace of the glass vial were collected with a gastight syringe, and the sampled headspace gas $(1 \mathrm{~mL})$ was injected into a GC equipped with a PFPD to calculate the peak area of the target organosulfur component. The deodorant activities of the test chemicals were calculated using the following equation [21]:

Deodorant activity $(\%)=\frac{(C-S)}{C} \times 100(C$, peak area of control; S, peak area of sample $)$.

\subsection{Isolation and Identification of Reactants from $B C O$ and $A M$}

BCO $(0.5 \mathrm{~g})$ was dissolved with ethanol $(20 \mathrm{~mL})$ and $\mathrm{AM}(500 \mu \mathrm{L})$, mixed, and then kept at $55^{\circ} \mathrm{C}$ for $45 \mathrm{~min}$. Then, the ethanol was distilled away under reduced pressure at $50{ }^{\circ} \mathrm{C}$ using a rotary evaporator (yield $0.98 \mathrm{~g}$ ). The yellowish oil was fractionated by silica gel flash chromatography to obtain the subfraction (yield $0.62 \mathrm{~g}$ ). The separating conditions were as follows: column, SNAP KP-Sil Cartridge $25 \mathrm{~g}$ (normal silica gel column, particle size $50 \mu \mathrm{m}$, Biotage, Osaka, Japan); mobile phase, hexane-ethyl acetate (gradient, 5-25\% $v / v$, ethyl acetate in hexane); and detection at UV $254 \mathrm{~nm}$. The obtained subfraction $(82 \mathrm{mg})$ was purified by silica gel flash chromatography with hexane-ethyl acetate (gradient, 5-22\% $v / v$, ethyl acetate in hexane) to obtain compound (1) (3 mg), compound (2) (8 mg), and compound (3) (5 mg).

Compound (1): yellowish oil; ${ }^{1} \mathrm{H}$ NMR $(400 \mathrm{MHz}) \mathrm{CDCl}_{3} \delta(\mathrm{ppm}): 6.90(1 \mathrm{H}, \mathrm{s}), 6.54$ $(1 \mathrm{H}, \mathrm{s}), 5.82(1 \mathrm{H}, \mathrm{ddt}, J=18.1,10.0,7.2 \mathrm{~Hz}), 5.01(1 \mathrm{H}, \mathrm{d}, J=10.0 \mathrm{~Hz}), 4.96(1 \mathrm{H}, \mathrm{dd}, J=18.1$, $1.3 \mathrm{~Hz}), 4.31(1 \mathrm{H}$, br. s) $, 3.83(1 \mathrm{H}, \mathrm{sext}, J=7.0 \mathrm{~Hz}), 3.23(2 \mathrm{H}, \mathrm{d}, J=7.2 \mathrm{~Hz}), 2.19(3 \mathrm{H}, \mathrm{s}), 1.38$ $(6 \mathrm{H}, \mathrm{d}, J=7.0 \mathrm{~Hz}) .{ }^{13} \mathrm{C}$ NMR $(100 \mathrm{MHz}) \mathrm{CDCl}_{3} \delta(\mathrm{ppm}): 149.8,147.2,135.0,133.0,121.6$,

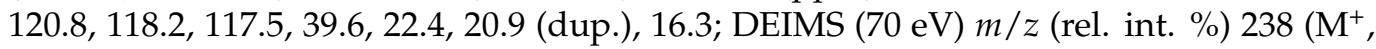
15.4), 195 (100), 180 (70.3), 162 (19.5), 155 (16.7), 57 (9.6).

Compound (2): yellowish oil; ${ }^{1} \mathrm{H}$ NMR $(400 \mathrm{MHz}) \mathrm{CDCl}_{3} \delta(\mathrm{ppm}): 6.81(1 \mathrm{H}, \mathrm{s}), 6.70$ $(1 \mathrm{H}, \mathrm{s}), 5.80(1 \mathrm{H}, \mathrm{ddt}, J=16.8,9.9,7.2 \mathrm{~Hz}), 4.97(1 \mathrm{H}, \mathrm{d}, J=9.9 \mathrm{~Hz}), 4.91(1 \mathrm{H}, \mathrm{dd}, J=16.8,1.3$ $\mathrm{Hz}), 4.45(1 \mathrm{H}, \mathrm{s}), 3.24(1 \mathrm{H}, \mathrm{sext}, J=7.0 \mathrm{~Hz}), 3.22(2 \mathrm{H}, \mathrm{d}, J=7.2 \mathrm{~Hz}), 2.40(3 \mathrm{H}, \mathrm{s}), 1.20(6 \mathrm{H}$, $\mathrm{d}, J=7.0 \mathrm{~Hz}) .{ }^{13} \mathrm{C}$ NMR $(100 \mathrm{MHz}) \mathrm{CDCl}_{3} \delta$ (ppm): 148.9, 146.7, 133.0, 132.3, 125.2, 118.2, 118.1, 114.9, 38.6, 27.6, 22.4 (dup.), 14.1; DEIMS (70 eV) $\mathrm{m} / z$ (rel. int. \%) $238\left(\mathrm{M}^{+}, 73.8\right), 203$ (18.5), 197 (100), 164 (62.8), 163 (48.3), 99 (24.4), 91 (27.5), 67 (30.3). 
Compound (3): yellowish oil; ${ }^{1} \mathrm{H}$ NMR (400 MHz) $\mathrm{CDCl}_{3} \delta(\mathrm{ppm}): 6.83(1 \mathrm{H}, \mathrm{s}), 6.70$ $(1 \mathrm{H}, \mathrm{s}), 5.74(1 \mathrm{H}, \mathrm{ddt}, J=13.2,6.4,7.2 \mathrm{~Hz}), 5.07(1 \mathrm{H}, \mathrm{d}, J=6.4 \mathrm{~Hz}), 5.03(1 \mathrm{H}, \mathrm{dd}, J=13.2$, $1.4 \mathrm{~Hz}), 4.39(1 \mathrm{H}, \mathrm{s}), 3.25(1 \mathrm{H}$, sext, $J=7.1 \mathrm{~Hz}), 3.07(2 \mathrm{H}, \mathrm{d}, J=7.2 \mathrm{~Hz}), 2.70(2 \mathrm{H}, \mathrm{t}, J=7.2$ $\mathrm{Hz}), 2.52(2 \mathrm{H}, \mathrm{t}, J=7.1 \mathrm{~Hz}), 2.41(3 \mathrm{H}, \mathrm{s}), 1.78(2 \mathrm{H}, \mathrm{q}, J=7.3 \mathrm{~Hz}), 1.20(6 \mathrm{H}, \mathrm{d}, J=6.8 \mathrm{~Hz}) .{ }^{13} \mathrm{C}$ NMR (100 MHz) $\mathrm{CDCl}_{3} \delta$ (ppm): 148.8, 146.9, 134.2, 132.3, 125.0, 118.8, 117.1, 114.8, 34.6, 34.3, 29.5, 28.9, 27.6, 22.4 (dup.), 14.1; DEIMS (70 eV) $m / z$ (rel. int. \%) $312\left(\mathrm{M}^{+}, 14.4\right), 271$ (15.9), 269 (100), 87 (16.0), 73 (53.0), 67 (28.2).

\subsection{Reaction Monitoring between Thymoquinone and AM}

The fixed amount of ethanolic solution $(1 \mathrm{~mL})$ of thymoquinone $(400 \mu \mathrm{g})$ and the fixed amount of ethanolic solution of AM $(0.05 \mathrm{~mL})$ were added to the buffer solution $(\mathrm{pH} 1.2$ or $7.0,5 \mathrm{~mL}$ ), sealed, and kept at $37^{\circ} \mathrm{C}$ for 10,30 , or $60 \mathrm{~min}$. The buffer solution was similar to that used in the evaluation of the deodorant activity. The amount of thymoquinone $(400 \mu \mathrm{g})$ was equivalent to $1 \mathrm{mg}$ of BCO. In this test, the applied concentrations of AM were 50,5 , and $0.5 \mu \mathrm{g} / \mathrm{mL}$.

The following analysis conditions were used: column, L-column 2 ODS (2.1 mm I.D. $\times 150 \mathrm{~mm}$, particle size $2.0 \mu \mathrm{m}$ ); detector, $U V, 254 \mathrm{~nm}$; flow rate, $0.4 \mathrm{~mL} / \mathrm{min}$; mobile phase, water:acetonitrile $=27: 73$; oven temperature, $40{ }^{\circ} \mathrm{C}$; and injection volume, $2 \mu \mathrm{L}$. The electrospray ionization mass spectrometry (ESI-MS) parameters were as follows: interface temperature, $300{ }^{\circ} \mathrm{C}$; desolvation line (DL) temperature, $250{ }^{\circ} \mathrm{C}$; heat block temperature, $400{ }^{\circ} \mathrm{C}$; nebulizer gas flow rate, $3 \mathrm{~L} / \mathrm{min}$; heating gas flow rate, $10 \mathrm{~L} / \mathrm{min}$; and drying gas flow rate, $10 \mathrm{~L} / \mathrm{min}$. The multiple reaction monitoring (MRM) mode was used to monitor the transition of compound (1) $(m / z: 237.10>196.10)$, compound $(2)(m / z: 237.10>196.10)$, and compound (3) $(m / z: 310.10>195.05)$. The retention times of compounds $\mathbf{1}-\mathbf{3}$ were 2.33, 2.21 , and $3.24 \mathrm{~min}$, respectively.

\subsection{Statistical Analysis}

All data were analyzed statistically by one-way analysis of variance followed by multiple comparison tests using the Tukey-Kramer test. The analyses were performed using Bell Curve for Excel (Version 3.21, Social Survey Research Information Co., Ltd., Tokyo, Japan) an add-in software for Excel.

\section{Results and Discussion}

\subsection{Organosulfur Compound Composition of GEO}

The major organosulfur compounds in GEO according to the GC-MS analysis were allyl mercaptan (AM), allyl methyl sulfide (AMS), diallyl sulfide (DAS), allyl methyl disulfide (AMDS), dimethyl trisulfide (DMTS), diallyl disulfide (DADS), allyl methyl trisulfide (AMTS), and diallyl trisulfide (DATS). The area percentages of each organosulfur compound toward the total area of the GC peaks in GEO were $0.14 \%, 2.00 \%, 6.24 \%$, $3.90 \%, 7.17 \%, 13.2 \%, 16.6 \%$, and $40.2 \%$, respectively. The major constituent of GEO was DATS (Figure 1). The organosulfur compound compositions of GEO from air-dried and freeze-dried garlic have been found to be characterized by an amount of organosulfur compound (84.3-98.9\%) consisting of DATS (37.3-45.9\%), DADS (17.5-35.6\%), and AMTS (7.7-10.4\%) [22]. In essential oil analyses of garlic varieties, the chemical composition has been found to consist of AMS (4.4-12.0\%), DAS (1.3-2.4\%), DMTS (0.5-2.2\%), DADS (27.1-46.8\%), AMTS (8.3-18.2\%), and DATS (19.9-34.7\%) [23]. Based on these reports, the GEO used in this study was considered to be a typical GEO. 
(a)

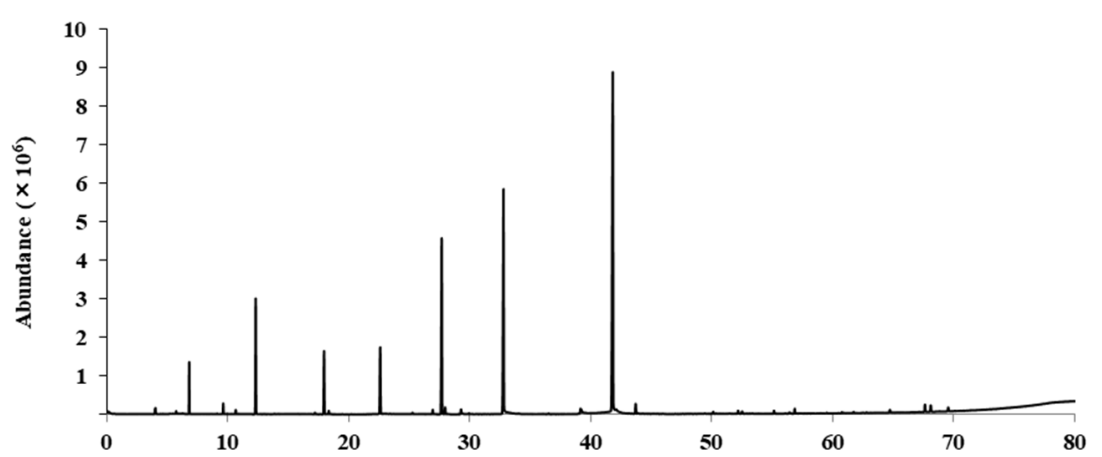

(b)

\begin{tabular}{|c|c|c|c|c|c|c|c|c|}
\hline $\begin{array}{l}\text { Peak } \\
\text { No. }\end{array}$ & $\mathrm{RT}^{\mathbf{l})}$ & $\mathbf{R I}^{2)}$ & $\begin{array}{l}\text { Sulfur compounds } \\
\text { name }\end{array}$ & Area (\%) & Boiling Point & $\mathbf{M w}^{3)}$ & $\log P^{4)}(0 / w)$ & Structure \\
\hline 1 & 5.65 & 848 & $\begin{array}{l}\text { Allyl Mercaptan } \\
\text { (AM) }\end{array}$ & 0.14 & $68^{* 22}$ & 74.15 & 1.507 & \\
\hline 2 & 6.71 & 924 & $\begin{array}{l}\text { Allyl Methyl Sulfide } \\
\text { (AMS) }\end{array}$ & 2.00 & $92.5 \% 23$ & 88.17 & 1.530 & \\
\hline 3 & 12.05 & 1118 & $\begin{array}{l}\text { Diallyl Sulfide } \\
\text { (DAS) }\end{array}$ & 6.24 & $138 * 24$ & 114.21 & 3.367 & \\
\hline 4 & 17.59 & 1245 & $\begin{array}{l}\text { Allyl Methyl Disulfide } \\
\text { (AMDS) }\end{array}$ & 3.90 & $\begin{array}{l}141.4 \pm 19.0 \\
\text { (predicted) }\end{array}$ & 120.2 & 2.871 & \\
\hline 5 & 22.17 & 1340 & $\begin{array}{l}\text { Dimethyl Trisulfide } \\
\text { (DMTS) }\end{array}$ & 7.17 & $170 ※ 25$ & 126.3 & 1.926 & \\
\hline 6 & 27.23 & 1441 & $\begin{array}{l}\text { Diallyl Disulfide } \\
\text { (DADS) }\end{array}$ & 13.2 & $137-198 * 26$ & 146.3 & 3.500 & \\
\hline 7 & 32.29 & 1545 & $\begin{array}{l}\text { Allyl Methyl Trisulfide } \\
\text { (AMTS) }\end{array}$ & 16.6 & $\begin{array}{l}212.7 \pm 33.0 \\
\text { (predicted) } * *\end{array}$ & 152.3 & 2.647 & \\
\hline 8 & 41.29 & 1742 & $\begin{array}{l}\text { Diallyl Trisulfide } \\
\text { (DATS) }\end{array}$ & 40.2 & $\begin{array}{l}229.5 \pm 43.0 \\
\text { (predicted) ** }\end{array}$ & 178.3 & 3.367 & \\
\hline
\end{tabular}

1) Retention time, 2) Retention index, 3) Pubchem, 4) The Good Scents Company ※Reference Number, ※※Calculated using Advanced Chemistry Development (ACD/Labs) Software V11.02 (@ 1994-2021 ACD/Labs)

Figure 1. Organosulfur compound composition of GEO: (a) GC-MS total ion chromatogram, (b) contents and structures of organosulfur compounds in GEO.

\subsection{Deodorant Activity of Black Cumin Seed Essential Oil (BCO) against GEO}

In a $30 \mathrm{~mL}$ glass vial, $\mathrm{BCO}(10 \mathrm{mg})$ showed remarkable deodorant activity at $\mathrm{pH} 1.2$ at $180 \mathrm{~min}$ after treatment. The deodorant activities of AMS, DAS, AMDS, DMTS, DADS, and AMTS were $56.3 \%, 72.4 \%, 59.0 \%, 69.5 \%, 28.4 \%$, and $32.0 \%$, respectively (Figure 2). The deodorant activities of AMS, DAS, AMDS, and DMTS were time-dependent, but DADS and AMTS were time-independent between $60 \mathrm{~min}$ and $120 \mathrm{~min}$ (Figure 3). We presume that DADS and AMTS have bulky structures and highly lipophilic properties compared to other compounds, and DADS and AMTS were difficult to volatilize into the headspace (Figure 1). 
(a)

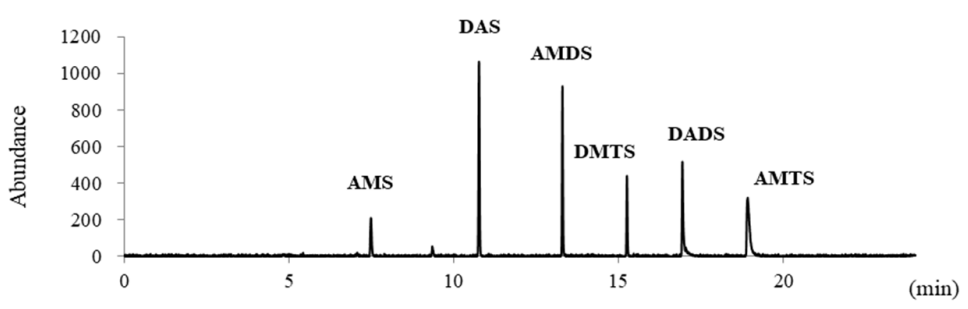

(b)

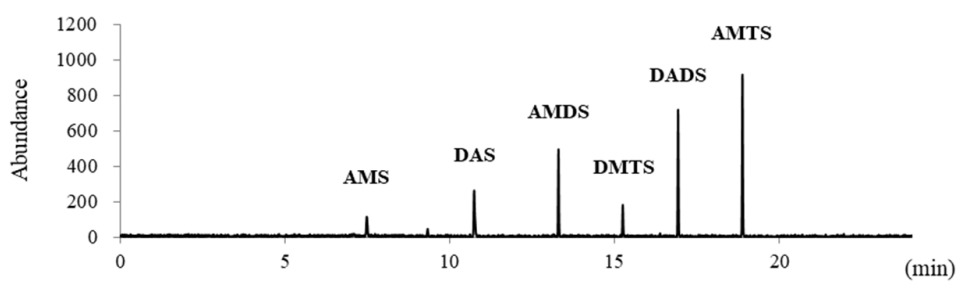

Figure 2. PFPD chart of deodorant activity of $\mathrm{BCO}$ against $15 \mu \mathrm{g}$ of $\mathrm{GEO}$ at $\mathrm{pH}$ 1.2: (a) without $\mathrm{BCO}$, (b) $10 \mathrm{mg}$ of BCO added to GEO for $180 \mathrm{~min}$.

(a) AMS

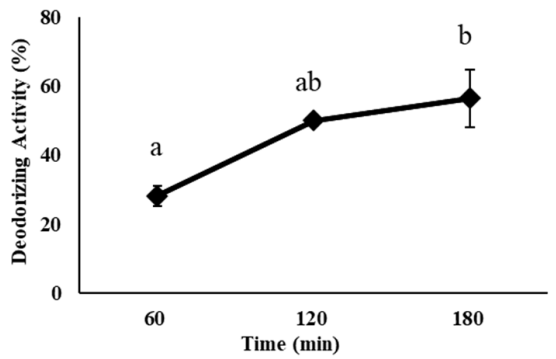

(b) DAS

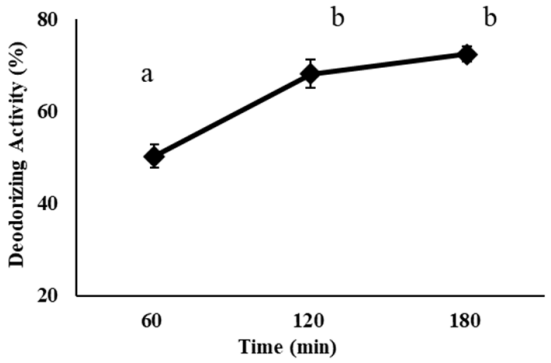

(c) AMDS

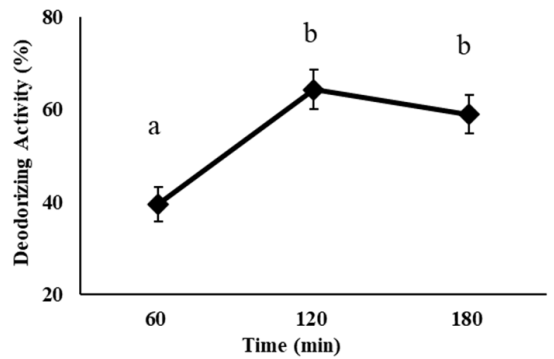

(d) DMTS

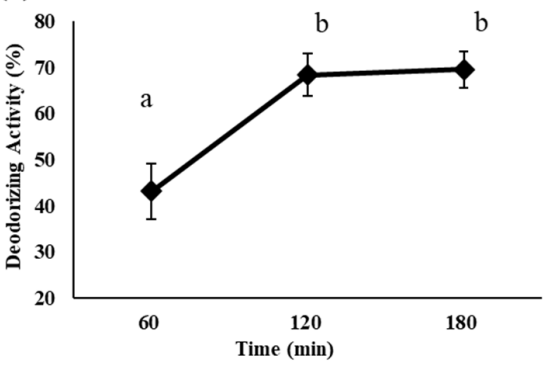

(e) DADS

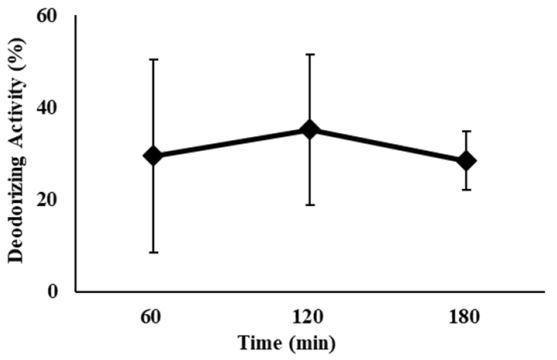

(f) AMTS

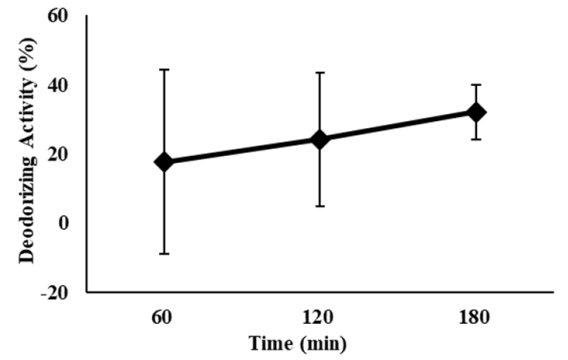

Figure 3. Deodorant activity of BCO against organosulfur compounds in GEO at pH 1.2: (a) AMS, (b) DAS, (c) AMDS, (d) DMTS, (e) DADS and (f) AMTS. Dosage of BCO, 10 mg, dosage of GEO, $15 \mu \mathrm{g}$. Values were shown as means with standard error as error bars $(n=3)$ with different letters to show significant differences $(p<0.05)$. 
Unfortunately, AM and DATS were not detectable under the selected analytical conditions. Presumably, the amount of AM in GEO was very low and DATS had a high boiling point, and they could not sufficiently vaporize into the headspace to be detected by GC with a PFPD (Figure 1).

\subsection{Deodorant Activity of BCO against Organosulfur Compounds}

In a $30 \mathrm{~mL}$ glass vial, the $0.1 \mathrm{mg}$ treatment of $\mathrm{BCO}$ showed remarkable deodorant activity against $0.5 \mu \mathrm{g}$ of $\mathrm{AM}(75.7 \%$ at $\mathrm{pH} 7.0,18.7 \%$ at $\mathrm{pH} 1.2)$. Under the same conditions, the $10 \mathrm{mg}$ treatment of BCO showed deodorant activity against $0.5 \mu \mathrm{g}$ of $\mathrm{AM}(100 \%$ at $\mathrm{pH}$ $7.0,70.2 \%$ at $\mathrm{pH} 1.2$ ) (Table 1). The deodorant activity of BCO was dose-dependent, but it was decreased at $\mathrm{pH} 1.2$ compared to $\mathrm{pH}$ 7.0. Additionally, the deodorant activity of $\mathrm{BCO}$ was effective against all test organosulfur compounds at $\mathrm{pH} 1.2$ (Table 2). This result suggests that BCO may decrease the amount of organosulfur compound derived from garlic in the stomach, and thus reduce halitosis due to belching. As previously mentioned, common halitosis involves oral odors, and many reports have involved tests performed at $\mathrm{pH}$ 7.0. However, in this study, we focused on deodorant activity in the stomach rather than the oral cavity. Specifically, we evaluated deodorant activity in a gastric environment at $\mathrm{pH} 1.2$, since the garlic halitosis almost always arises from the decomposition of garlic organosulfur compounds in the stomach. As shown in Table 1, our comparative studies of $\mathrm{pH} 1.2$ and $\mathrm{pH} 7.0$ showed that the deodorant activity against AM tended to be lower under the $\mathrm{pH} 1.2$ condition. Although GEO has low AM content, a considerable amount of AM is detected in the breath of humans who consume garlic [24]. The odor of garlic is known to derive from alliin. When raw garlic is crushed or minced, alliin is converted to allicin by alliinase. However, allicin is unstable and easy to decompose into various organosulfur compounds, such as DADS, DATS, and ajoene. Furthermore, DADS and DATS are converted to AM, followed by conversion to AMS [14,25]. These results suggest that BCO may act as a deodorizing agent, thereby preventing halitosis after garlic meal ingestion.

Table 1. Deodorant activity of black cumin seed oil (BCO) against $0.5 \mu \mathrm{g}$ of allyl mercaptan (AM).

\begin{tabular}{ccc}
\hline Assay Condition & Dosage of BCO (mg) & Deodorant Activity \pm SD (\%) \\
\hline pH 7.0 & 0.1 & $75.7 \pm 9.30$ \\
\cline { 2 - 3 } & 10 & $100 \pm 0.00$ \\
\hline pH 1.2 & 0.1 & $18.7 \pm 16.7$ \\
\hline
\end{tabular}

Incubation time; $10 \mathrm{~min}$. Each value represents the mean $\pm \mathrm{SD}(n=3)$.

\subsection{Isolation and Identification of Reactants between Thymoquinone and AM}

A few products of the reaction between thymoquinone and AM were isolated using silica gel flash chromatography with hexane and ethyl acetate as the mobile phase. The elucidation of the structures of these products was performed using ${ }^{1} \mathrm{H} \mathrm{NMR},{ }^{13} \mathrm{C}$ NMR, and 2D NMR (HSQC, HMBC) spectral data. Three reaction products, compounds (1-3) were identified in this study. Compounds 1 and 2 were AM added to dihydrothymoquinone, a reduced form of the major natural monoterpene thymoquinone in $\mathrm{BCO}$ (Figure 4). Compound 3 had a dithio-moiety from one extra AM added to 2 (Figure 4). This result suggests that the deodorizing mechanism of $\mathrm{BCO}$ against $\mathrm{AM}$ may have occurred due to the conversion of AM to these chemicals. 
Table 2. Deodorant activity of each dosage of black cumin seed oil (BCO) against sulfur compounds at $\mathrm{pH} 1.2$ assay buffer.

\begin{tabular}{cccc}
\hline \multirow{2}{*}{ Compounds } & \multicolumn{3}{c}{ Deodorant Activity \pm SD (\%) } \\
\cline { 2 - 4 } & $\mathbf{5} \mathbf{~ m g ~ o f ~ B C O}$ & $\mathbf{1 0} \mathbf{~ m g ~ o f ~ B C O}$ & $\mathbf{2 0 ~} \mathbf{~} \mathbf{~ o f ~ B C O}$ \\
\hline AMS & $31.6 \pm 2.72$ & $32.8 \pm 11.4$ & $49.5 \pm 8.14$ \\
\hline DAS & $58.9 \pm 1.27$ & $57.0 \pm 4.58$ & $81.2 \pm 2.11$ \\
\hline AMDS & $22.7 \pm 7.38$ & $65.1 \pm 6.76$ & $87.2 \pm 2.8$ \\
\hline DMTS & $61.8 \pm 11.0$ & $68.8 \pm 5.00$ & $85.9 \pm 3.23$ \\
\hline DADS & $43.6 \pm 6.52$ & $45.3 \pm 11.0$ & $100 \pm 0.00$ \\
\hline AMTS & $58.2 \pm 4.42$ & $82.5 \pm 2.21$ & $100 \pm 0.00$ \\
\hline DATS & $49.4 \pm 2.81$ & $73.7 \pm 1.59$ & $100 \pm 0.00$ \\
\hline
\end{tabular}

Each value represents the mean $\pm \mathrm{SD}(n=3)$. Incubation time: $120 \mathrm{~min}$ for AMS, DAS, and AMDS, $180 \mathrm{~min}$ for DMTS, DADS, AMTS, and DATS. Dosage: $500 \mathrm{ng}$ for AMS, DAS, AMDS, DMTS, and DADS; $25 \mu \mathrm{g}$ for AMTS; $50 \mu \mathrm{g}$ for DATS.<smiles>C=CCSc1c(O)c(C)cc(O)c1C(C)C</smiles>

(1)<smiles>C=CCSc1c(C)c(O)cc(C(C)C)c1O</smiles>

(2)<smiles>C=CCS1(c2c(C)c(O)cc(C(C)C)c2O)CCCS1</smiles>

(3)

Figure 4. The structure of reactants between $\mathrm{BCO}$ and $\mathrm{AM}$. 1: 3-Allylthiodihydrothymoquinone, 2: 2Allylthiodihydrothymoquinone, 3: 2-(1-Allyl-1,2-dithiolanyl)-dihydrothymoquinone.

A previous report concerning the prevention of bad breath due to garlic used various botanical sources containing polyphenols, such as apple, tea, lemon, parsley, and mint [26]. In our present study, AM was trapped with thymoquinone covalently and converted to a non-volatile phenol compound. However, a similar reaction could not be observed in the other tested sulfides in this study (data not shown). This fact suggested that a thiol moiety was essential to this reaction. A previous report described that some organosulfur compounds are converted to AM [27]; therefore, decreasing the AM amount may prevent AMS generation in the body.

A comparison of the effects of non-fat milk and whole milk on the deodorant activity of garlic reported that whole milk was more effective. However, whole milk showed the highest efficacy in comparison with water, whole milk, and $10 \%$ casein sodium aq., and it was presumed that the fat contained in whole milk suppressed the volatility of the garlic-derived DAS and AMS [13]. Similarly, the deodorant activity of BCO presumed that not only covalent trapping between thymoquinone and AM but also high hydrophobicity interactions occurred in this study.

\subsection{Reaction Monitoring between Thymoquinone and AM}

The time-dependent reactions between thymoquinone and $\mathrm{AM}$ at $\mathrm{pH} 7.0$ were measured. Although the amounts of thymoquinone and AM did not decrease drastically, the amounts of their adducts, compounds 2 and 3, increased in a time-dependent manner (Figure 5a-c). Similarly, the amounts of AM and thymoquinone did not decrease drastically, but the amounts of their adducts, compounds 1-3, increased in a time-dependent manner at $\mathrm{pH} 1.2$ (Figure $5 \mathrm{~d}-\mathrm{f}$ ). The amounts of reactants $\mathbf{1}-\mathbf{3}$ were dependent on the acidic conditions in this study (Table 3 ). 
(a)

pH 7.0

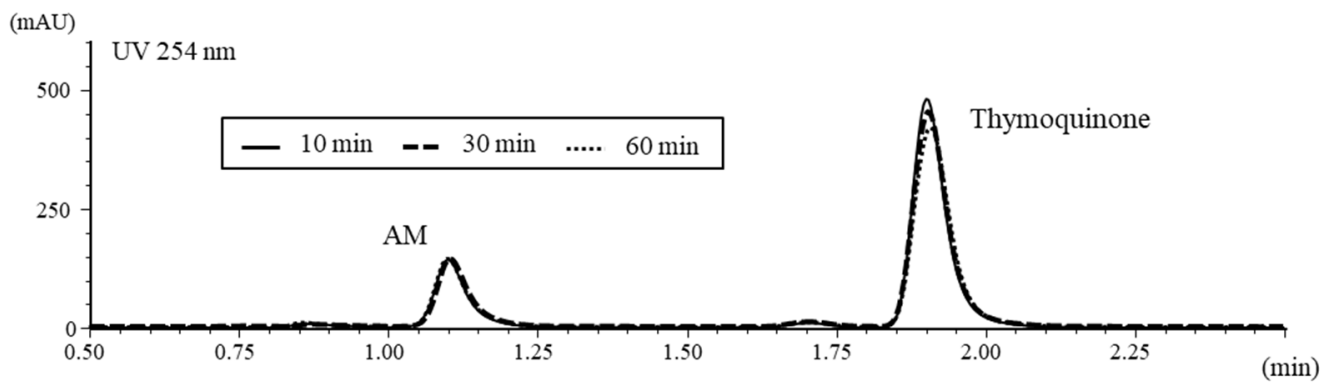

(b)

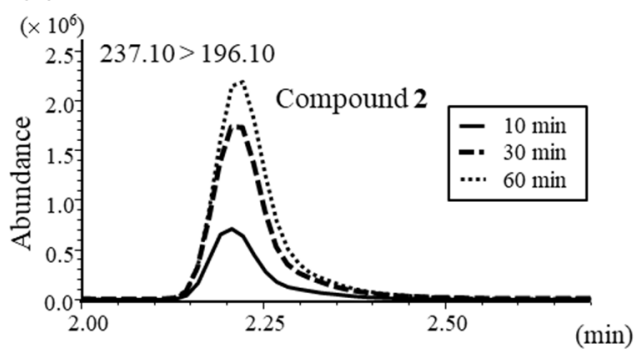

(c)

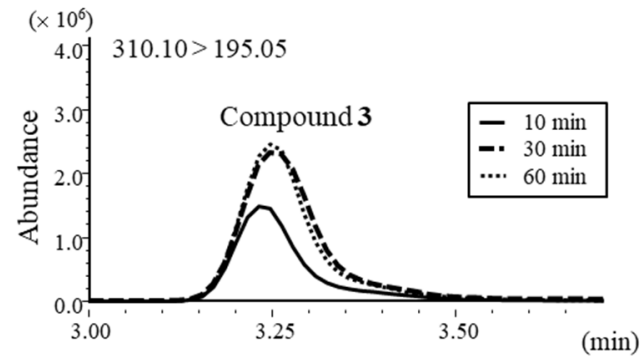

(d)

pH 1.2

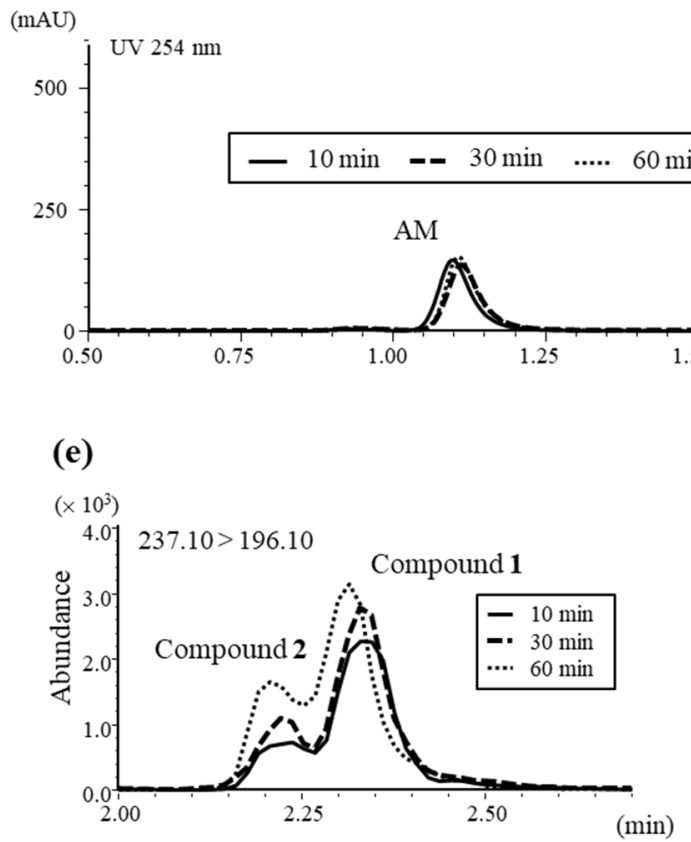

(f)

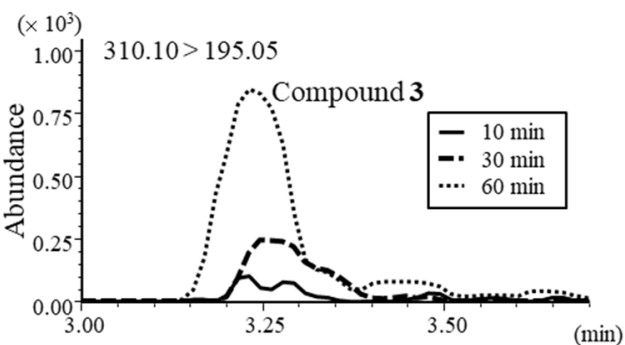

Figure 5. The chromatograph after reaction with $400 \mu \mathrm{g}$ of thymoquinone and AM: (a) HPLC chart at $254 \mathrm{~nm}$ of thymoquinone and AM after reaction at pH 7.0, (b) MS chromatograph (MRM $237.10>196.10$ ) after reaction at $\mathrm{pH} 7.0$, (c) MS chromatograph (MRM $310.10>195.05$ ) after reaction at $\mathrm{pH} 7.0$, (d) HPLC chart at $254 \mathrm{~nm}$ of thymoquinone and AM after reaction at $\mathrm{pH} 1.2$, (e) MS chromatograph (MRM 237.10 > 196.10) after reaction at pH 1.2, (f) MS chromatograph (MRM $310.10>195.05)$ after reaction at $\mathrm{pH} 1.2$. All experiments were performed at $37^{\circ} \mathrm{C}$. 
Table 3. The yield of each reactant after reaction with $400 \mu \mathrm{g}$ of thymoquinone and each quantity of allyl mercaptan (AM).

\begin{tabular}{|c|c|c|c|c|c|}
\hline \multirow{2}{*}{$\begin{array}{c}\text { Reaction } \\
\text { pH }\end{array}$} & \multirow{2}{*}{$\begin{array}{l}\text { Time } \\
(\mathrm{min})\end{array}$} & \multirow{2}{*}{$\begin{array}{l}\text { Quantity of } \\
\text { AM ( } \mu g)\end{array}$} & \multicolumn{3}{|c|}{ Content \pm SD (ng/mL) } \\
\hline & & & Reactant 1 & Reactant 2 & Reactant 3 \\
\hline \multirow{9}{*}{1.2} & \multirow{3}{*}{10} & 0.5 & n.d. & n.d. & n.d. \\
\hline & & 5 & $0.14 \pm 0.24$ & $0.02 \pm 0.04$ & n.d. \\
\hline & & 50 & $4.05 \pm 3.52$ & $1.81 \pm 0.88$ & $0.08 \pm 0.07$ \\
\hline & \multirow{3}{*}{30} & 0.5 & n.d. & n.d. & n.d. \\
\hline & & 5 & $0.16 \pm 0.28$ & $0.06 \pm 0.10$ & n.d. \\
\hline & & 50 & $8.12 \pm 2.47$ & $2.96 \pm 0.85$ & $0.22 \pm 0.05$ \\
\hline & \multirow{3}{*}{60} & 0.5 & n.d. & n.d. & n.d. \\
\hline & & 5 & $0.28 \pm 0.48$ & $0.14 \pm 0.24$ & $0.02 \pm 0.03$ \\
\hline & & 50 & $10.08 \pm 1.83$ & $5.66 \pm 0.22$ & $0.68 \pm 0.31$ \\
\hline \multirow{9}{*}{7.0} & \multirow{3}{*}{10} & 0.5 & n.d. & $0.26 \pm 0.28$ & $0.21 \pm 0.20$ \\
\hline & & 5 & n.d. & $5.58 \pm 3.6$ & $4.31 \pm 1.23$ \\
\hline & & 50 & n.d. & $422.69 \pm 194.55$ & $163.23 \pm 38.93$ \\
\hline & \multirow{3}{*}{30} & 0.5 & n.d. & $1.42 \pm 1.41$ & $0.50 \pm 0.55$ \\
\hline & & 5 & n.d. & $18.42 \pm 11.45$ & $10.27 \pm 0.77$ \\
\hline & & 50 & n.d. & $605.32 \pm 123.83$ & $231.97 \pm 49.12$ \\
\hline & \multirow{3}{*}{60} & 0.5 & n.d. & $2.13 \pm 2.12$ & $0.70 \pm 0.63$ \\
\hline & & 5 & n.d. & $28.38 \pm 13.47$ & $11.29 \pm 0.32$ \\
\hline & & 50 & n.d. & $732.26 \pm 176.18$ & $261.43 \pm 36.45$ \\
\hline
\end{tabular}

n.d.: not detected. Each value represents the mean $\pm \mathrm{SD}(n=3)$.

When $50 \mu \mathrm{g}$ of $\mathrm{AM}$ was added to $400 \mu \mathrm{g}$ of thymoquinone at $\mathrm{pH} 1.2$, compound 1 occurred in concentrations of $4.05,8.12$, and $10.08 \mathrm{ng} / \mathrm{mL}$ at 10,30 , and $60 \mathrm{~min}$ after mixture, respectively. At $\mathrm{pH} 7.0$, the concentrations of compound 1 were all not detected (N.D.) at 10, 30, and $60 \mathrm{~min}$ after mixture, respectively. Similarly, the concentrations of compound 2 were $1.81,2.96$, and $5.66 \mathrm{ng} / \mathrm{mL}$ at $\mathrm{pH} 1.2$ at 10, 30, and $60 \mathrm{~min}$, respectively. At $\mathrm{pH} 7.0$, the concentrations of compound 2 were $422.69,605.32$, and $732.26 \mathrm{ng} / \mathrm{mL}$ at 10 , 30 , and $60 \mathrm{~min}$, respectively. The concentrations of compound 3 were $0.08,0.22$, and 0.68 $\mathrm{ng} / \mathrm{mL}$ at $\mathrm{pH} 1.2$ and 163.23, 231.97, and $261.43 \mathrm{ng} / \mathrm{mL}$ at $\mathrm{pH} 7.0$ at 10, 30, and $60 \mathrm{~min}$, respectively.

On the other hand, when $5 \mu \mathrm{g}$ of $\mathrm{AM}$ was added, at $\mathrm{pH} 1.2$, compound 1 occurred in concentrations of $0.14,0.16$, and $0.28 \mathrm{ng} / \mathrm{mL}$ at 10,30 , and $60 \mathrm{~min}$ after mixture, respectively. At $\mathrm{pH}$ 7.0, the concentrations of compound 1 were all N.D. at 10, 30, and $60 \mathrm{~min}$ after mixing, respectively. Similarly, the concentrations of compound 2 were $0.02,0.06$, and $0.14 \mathrm{ng} / \mathrm{mL}$ at $\mathrm{pH} 1.2$ at 10,30, and $60 \mathrm{~min}$, respectively. At $\mathrm{pH} 7.0$, the concentrations of compound 2 were $5.58,18.42$, and $28.38 \mathrm{ng} / \mathrm{mL}$ at 10,30 , and $60 \mathrm{~min}$, respectively. The concentrations of compound 3 were N.D., N.D., and $0.02 \mathrm{ng} / \mathrm{mL}$ at $\mathrm{pH} 1.2$ and 4.31, 10.27, and $11.29 \mathrm{ng} / \mathrm{mL}$ at $\mathrm{pH} 7.0$ at 10,30, and $60 \mathrm{~min}$, respectively. When $0.5 \mu \mathrm{g}$ of AM was added, compound 1 was N.D. at both pH 1.2 and pH 7.0. Similarly, compound 2 was N.D. at $\mathrm{pH} 1.2$ at 10, 30, and $60 \mathrm{~min}$, respectively. At $\mathrm{pH} 7.0$, the concentrations of compound 2 were $0.26,1.42$, and $2.13 \mathrm{ng} / \mathrm{mL}$ at 10,30 , and $60 \mathrm{~min}$, respectively. The concentrations of compound 3 were all N.D. at $\mathrm{pH} 1.2$ and $0.21,0.50$, and $0.70 \mathrm{ng} / \mathrm{mL}$ at pH 7.0 at 10, 30, and $60 \mathrm{~min}$, respectively.

The reaction between $\mathrm{AM}$ and thymoquinone was promoted at $\mathrm{pH} 7.0$ in comparison with $\mathrm{pH}$ 1.2. These results were similar to those of the deodorant evaluations using HS-GC. 


\section{Conclusions}

The results obtained for the deodorant activity of $\mathrm{BCO}$ against garlic odor suggest that this botanical resource applies to the control of oral malodor after consuming garlic meals. Previous papers about deodorant activity had evaluated this under oral environmental conditions of $\mathrm{pH} 7.0$, while this study also evaluated gastric environmental conditions of $\mathrm{pH}$ 1.2. In this study, we discovered that BCO was effective in suppressing bad breath after intaking a garlic meal. We presumed that a part of the mechanism that is a major constituent of BCO, thymoquinone, trapped AM, which is an organosulfur produced from garlic meals in the human body causative of garlic bad breath. However, this deodorant activity of $\mathrm{BCO}$ did not overwhelm the odor, and the other non-reacted garlic organosulfur compounds remained in the human body. These residual intact garlic organosulfur compounds, such as DADS and AMTS, may have various valuable bioavailability in the human body. Recently, we showed that garlic organosulfur compounds had the potential to slow the procession of Alzheimer's disease by the inhibition of related enzymes located in the brain [28]. Although the deodorant activity of $\mathrm{BCO}$ is effective in controlling oral malodor from garlic meals, it is better to adjust the intake time to interval eating for garlic bioavailability. It is a critical point from a good human health point of view that the bioavailability of garlic organosulfur compounds increases and the deodorant activity of BCO follows. Finally, research on the deodorizing mechanisms of $\mathrm{BCO}$ is likely to continue in the future. People who consume garlic products for health benefits, such as revitalizing cells and the bloodstream, could prevent bad breath due to the odor of garlic by taking BCO.

Author Contributions: Conceptualization, Y.Y. and S.M.; methodology, Y.Y., S.M. and M.M.; validation, Y.Y., S.M. and M.M.; formal analysis, Y.Y., S.M. and M.M.; investigation, Y.Y., S.M. and M.M.; resources, Y.Y. and S.M.; data curation, Y.Y., S.M. and M.M.; writing-original draft preparation, Y.Y and M.M.; writing-review and editing, M.M.; visualization, Y.Y; supervision, M.M.; project administration, Y.Y. All authors have read and agreed to the published version of the manuscript.

Funding: This research received no external funding.

Institutional Review Board Statement: Not applicable.

Informed Consent Statement: Not applicable.

Data Availability Statement: Data sharing is not applicable to this article.

Conflicts of Interest: The authors declare no conflict of interest.

\section{References}

1. Mahmoodi, M.R.; Mohammadizadeh, M. Therapeutic potentials of Nigella sativa preparations and its constituents in the management of diabetes and its complications in experimental animals and patients with diabetes mellitus: A systematic review. Complement. Ther. Med. 2020, 50, 102391. [CrossRef] [PubMed]

2. El-Saber Batiha, G.; Magdy Beshbishy, A.; GWasef, L.; Elewa, Y.H.A.; AAl-Sagan, A.; Abd El-Hack, M.E.; Taha, A.E.; MAbdElhakim, Y.; Prasad Devkota, H. Chemical constituents and pharmacological activities of garlic (Allium sativum L.): A review. Nutrients 2020, 12, 872. [CrossRef] [PubMed]

3. Haggard, H.W.; Greenberg, L.A. Breath odors from alliaceous substances: Cause and remedy. JAMA 1935, 104, $2160-2163$. [CrossRef]

4. Rosen, R.T.; Hiserodt, R.D.; Fukuda, E.K.; Ruiz, R.J.; Zhou, Z.; Lech, J.; Rosen, S.L.; Hartman, T.G. Determination of allicin, S-allylcysteine and volatile metabolites of garlic in breath, plasma or simulated gastric fluids. J. Nutr. 2001, 131, 968S-971S. [CrossRef]

5. Nakatani, N.; Miura, K.; Inagaki, T. Structure of new deodorant biphenyl compounds from thyme (Thymus vulgaris L.) and their activity against methyl mercaptan. Agri. Biol. Chem. 1989, 53, 1375-1381. [CrossRef]

6. Yasuda, H.; Arakawa, T. Deodorizing mechanism of (-)-epigallocatechin gallate against methyl mercaptan. Biosci. Biotechnol. Biochem. 1995, 59, 1232-1236. [CrossRef]

7. Kim, Y.; Jang, S.-J.; Kim, H.-R.; Kim, S.-B. Deodorizing, antimicrobial and glucosyltransferase inhibitory activities of polyphenolics from biosource. Korean J. Chem. Eng. 2017, 34, 1400-1404. [CrossRef]

8. Nakasugi, T.; Murakawa, T.; Shibuya, K.; Morimoto, M. Deodorizing substance in black cumin (Nigella sativa L.) seed oil. J. Oleo Sci. 2017, 66, 877-882. [CrossRef] 
9. Negishi, O.; Negishi, Y. Enzymatic deodorization with raw fruits, vegetables and mushrooms. Food Sci. Technol. Res. 1999, 5, 176-180. [CrossRef]

10. Zhou, W.; Zou, X.; Lu, Y.; Xia, L.; Huang, C.; Shen, C.; Chen, X.; Chu, Y. Characterization of volatiles in garlic and in exhaled breath after garlic ingestion by on-line atmospheric pressure photoionization quadrupole time-of-flight mass spectrometry. Food Sci. Technol. Res. 2017, 23, 613-620. [CrossRef]

11. Taucher, J.; Hansel, A.; Jordan, A.; Lindinger, W. Analysis of compounds in human breath after ingestion of garlic using proton-transfer-reaction mass spectrometry. J. Agric. Food Chem. 1996, 44, 3778-3782. [CrossRef]

12. Suarez, F.; Springfield, J.; Furne, J.; Levitt, M. Differentiation of mouth versus gut as site of origin of odoriferous breath gases after garlic ingestion. Am. J. Physiol. 1999, 276, G425-G430. [CrossRef]

13. Hansanugrum, A.; Barringer, S.A. Effect of milk on the deodorization of malodorous breath after garlic ingestion. J. Food Sci. 2010, 75, 549-558. [CrossRef]

14. Sato, S.; Sekine, Y.; Kakumu, Y.; Hiramoto, T. Measurement of diallyl disulfide and allyl methyl sulfide emanating from human skin surface and influence of ingestion of grilled garlic. Sci. Rep. 2020, 10, 465. [CrossRef]

15. Degen, L.P.; Phillips, S.F. Variability of gastrointestinal transit in healthy women and men. Gut 1996, 39, 299-305. [CrossRef]

16. Hellmig, S.; Von Schöning, F.; Gadow, C.; Katsoulis, S.; Hedderich, J.; Fölsch, U.R.; Stüber, E. Gastric emptying time of fluids and solids in healthy subjects determined by $13 \mathrm{C}$ breath tests: Influence of age, sex and body mass index. J. Gastroen. Hepatol. 2006, 21, 1832-1838. [CrossRef]

17. Lawson, L.D.; Wang, Z.J.; Hughes, B.G. Identification and HPLC quantitation of the sulfides and dialk(en)yl thiosulfinates in commercial garlic products. Planta Med. 1991, 57, 363-370. [CrossRef]

18. Iberl, B.; Winkler, G.; Knobloch, K. Products of allicin transformation: Ajoenes and dithiins, characterization and their determination by HPLC. Planta Med. 1990, 56, 202-211. [CrossRef]

19. Miething, H. HPLC-analysis of the volatile oil of garlic bulbs. Phytother. Res. 1988, 2, 149-151. [CrossRef]

20. Clemente, J.G.; Williams, J.D.; Cross, M.; Chambers, C.C. Analysis of garlic cultivars using head space solid phase microextraction/gas chromatography/mass spectroscopy. Open Food Sci. J. 2012, 6, 1-4. [CrossRef]

21. Kita, N.; Fujimoto, K.; Nakajima, I.; Hayashi, R.; Shibuya, K. Screening test for deodorizing substances from marine algae and identification of phlorotannins as the effective ingredients in Eisenia bicyclis. J. Appl. Phycol. 1990, 2, 155-162. [CrossRef]

22. Dziri, S.; Casabianca, H.; Hanchi, B.; Hosni, K. Composition of garlic essential oil (Allium sativum L.) as influenced by drying method. J. Essent. Oil Res. 2014, 26, 91-96. [CrossRef]

23. Raghavan, R.; Rao, P.P.; Rao, L. Chemical composition of essential oils of garlic (Allium sativum L.). J. Spic. Arom. Crops. 1999, 8, 41-47.

24. Tamaki, T.; Sonoki, S. Volatile sulfur compounds in human expiration after eating raw or heat-treated garlic. J. Nutr. Sci. Vitaminol. 1999, 45, 213-222. [CrossRef]

25. Egen-Schwind, C.; Eckard, R.; Kemper, F.H. Metabolism of garlic constituents in the isolated perfused rat liver. Planta Med. 1992, 58, 301-305. [CrossRef]

26. Munch, R.; Barringer, S.A. Deodorization of garlic breath volatiles by food and food components. J. Food Sci. 2014, 79, 526-533. [CrossRef]

27. Lawson, L.D.; Wang, Z.J. Allicin and allicin-derived garlic compounds increase breath acetone through allyl methyl sulfide: Use in measuring allicin bioavailability. J. Agric. Food Chem. 2005, 53, 1974-1983. [CrossRef]

28. Yoshioka, Y.; Matsumura, S.; Morimoto, M.; Takemoto, Y.; Kishi, C.; Moriyama, T.; Zaima, N. Inhibitory activities of sulfur compounds in garlic essential oil against Alzheimer's disease-related enzymes and their distribution in the mouse brain. J. Agric. Food Chem. 2021, 69, 10163-10173. [CrossRef] 